\title{
RETELLING LEGENDS AND FOLK TALES: A TRANSCREATIVE APPROACH IN THE COLLABORATIVE TRANSLATION CLASSROOM*
}

\author{
OLGA MASTELA \\ Jagiellonian University in Kraków \\ olga.mastela@uj.edu.pl
}

\begin{abstract}
The objective of this paper is twofold: to present an authentic collaborative project devoted to the transcreation of different versions of Polish legends and folk tales (with eventual publication in an academic journal), as well as to demonstrate the advantages of applying the transcreative approach to translation in translator training at MA level. The project in question was accomplished in the academic year 2018/2019 by a team of the 1st and 2 nd year MA students, partly out of the classroom in an authentic setting and partly within the frames of a specialised collaborative translation course. The paper presents a new idea to teach translation, based on action research and the out-of-the-classroom approach to translator training, and includes a qualitative research case study of students' views on the project as well as some pedagogical implications, such as the proposal to introduce collaborative transcreation activities into translator training curricula.
\end{abstract}

Keywords: authentic learning environment, collaborative translation, folk tale, transcreation, translation pedagogy

\section{Introduction}

The importance of creating an authentic learning environment and engaging students in collaborative translation projects has been recognized in recent years by many translation teachers and scholars (cf. Dybiec-Gajer 2011; GonzálezDavies and Enríquez-Raído 2016; Kiraly 2016; Frérot, Lavault-Olléon and Karagouch 2019 and others). Kiraly, acknowledging "the links and synergies between functional translation theory and authentic translation projects in translator education", demonstrated in his action research that "an authentic project might be incorporated successfully into a translation practice classroom as an emergent phenomenon that can encourage students to understand translation as

Acknowledgements are due to Prof. Maria Piotrowska (Jagiellonian University) for initiating the transcreation project within the frames of pro-quality research, and to Prof. Linda Kean (East Carolina University) for reviewing the transcreations published in: Mastela and Seweryn (2019). 
complex professional behaviour" (2012: 142). Following this translation teaching methodology, translation trainers create simulations of translation bureaus or cooperate with translation agencies, publishing houses and other institutions to provide translation trainees with real-life experience. In order to prepare future translators for the demands of the market and translation industry, translation departments propose various additional activities, in and out of the classroom, thus making their translation courses more attractive and challenging for students. In this paper, examples of such activities will be presented through a case study of an authentic collaborative project devoted to the transcreation of selected Polish folk tales into English. The aim of the paper is therefore twofold: firstly, to present the project as a set of new ideas to teach translation and secondly, to demonstrate the advantages of introducing transcreation workshops into translator training at MA level.

According to Piotrowska (2020), one example of authentic out-of-classroom activities is a translational-ethnographic event organised in local "indigenous surroundings".

Imagine that you are sitting in a cosy armchair by a fireplace in a medieval fortress, listening to folk tales about the stronghold's past. This is exactly what we did in autumn 2018. We invited our students to travel with us to Niedzica Castle, situated by the Dunajec River in southern Poland, where we all took part in an extraordinary event. (Mastela and Seweryn 2019: 5)

The ultimate goal was the publication of English translations of selected Polish legends and folk tales, which constituted an additional motivation for students (cf. Piotrowska 2020). The translational-ethnographic event and its pedagogical advantages will be discussed in detail in Section 2.1..

Learning in authentic settings helps enhance numerous faculties, including memory, understanding, imagination and creativity. The latter has been gaining increasing importance in translation professions other than literary due to "public recognition of the worth of a professional translator's creative abilities" in general (Katan 2014: 10). There seems to be a need to introduce more activities enhancing translation trainees' creative thinking into translation courses (Morón and Calvo 2018; Piotrowska 2020).

In this era of technological advancement, resulting in the ever-growing use of CAT-tools in the translation industry, it seems obvious that within the field of translation teaching and translator training curricula attention should be drawn to yet another issue, which is the need to make students aware of cultural values and idioms, as well as to raise students' awareness of intertextual and intercultural content. Apart from teaching the proper use of modern technologies and making students co-responsible for the quality of team translation projects, trainers should also sensitise the learners to the crucial significance of the human factor and humanistic values in the translation process. Gill and Guzmán (2011), inspired by the American educator Chet Bowers (1997), noticed that 
in translation teaching, technological change is seen as inherently progressive, and technologies for fostering such change are given high status in our institutions. In such a paradigm, cultural knowledge and the anthropocentric view of the world can be quickly turned into commodities. We must create curricula that ensure that deep human cultural values do not fall into the status of low-category knowledge [...]. We believe it is our duty to empower students by helping them develop their critical consciousness, their own social vision that will help them become involved in our ever-changing societies. (2011: 107)

A similar view has been expressed in the 'European Master's in Translation' Competence Framework:

In the translation industry, technological change has had an ever-increasing impact on the way translation services are performed, though human intelligence, knowledge and skills are still the key factors in delivering quality translations and the growing range of language services which translators and translation companies can provide. (Toudic and Krause 2017: 2)

One of the most popular language services provided nowadays by translation companies, a service in the performance of which human intelligence and creativity are indispensable, is transcreation.

Though seemingly new, the term transcreation has been used both in the domain of literary (or artistic) translation and in the area of international commerce and marketing for some time now. In the domain of globalised brands and commerce, transcreation usually refers to "the adaptation of advertising material for different markets" (Pedersen 2014: 57). As Pedersen summarises the ways in which the term is understood by transcreation service providers, both the process and the product of transcreation seek "to perform all the adjustments necessary to make a campaign work in all target markets, while at the same time staying loyal to the original creative intent of the campaign" (2014: 58). Though not specifically defined as such, it is probable that it is this meaning of 'transcreation' which is included in the "Non-exhaustive list of value added services" in Annex F to the European Standard providing Requirements for translation services (EN ISO 17100:2015). In the context of various language services, transcreation itself is usually advertised as something "more than translation" (Pedersen 2014: 62) and as such is claimed to be "a specialism", "an extra service" which may be more expensive than "a more prosaic translation" (Gambier and Munday 2014: 20).

In the domain of literary translation, transcreative practices resulting in particularly creative adaptations of literary works have been present for decades, if not for centuries as in the case of Indian literature (cf. Bassnett, Trivedi 1999: 10). Purushottama Lal, who introduced the term transcreation as the name for the particular Indian concept of creative literary adaptation, describes his own translation of Sanskrit plays into English in the following words: "faced with such a variety of material, the translator must edit, reconcile, and transmute; his job in 
many ways becomes largely a matter of transcreation" ([1957] 1964: 5). In 1960s, the term transcreation (in Brazilian Portuguese - transcriação) was used by a Brazilian translator and poet Haroldo de Campos, who understood it as "a transformative recreation of inherited tradition" (Vieira 1999: 97). According to Campos, to "transcreate is not to try to reproduce the original's form understood as a sound pattern, but [...] to use the local existing tradition" (cit. in Vieira 1999: 110).

Following Dybiec-Gajer and Oittinen (2020: 3), it seems reasonable to understand transcreation as a specific category of translation "concerned more with effect and emotions than meaning", taking into account that "transcreation is not only about communicating effectively, but also affectively, establishing an emotional connection between the audience/the customer and the message", which is of paramount importance, for example, in retelling children's literature. As legends and folk tales - prototypically telling stories of places and their ancient inhabitants and often containing moral lessons - are genres aimed primarily at younger audiences, adopting the transcreational perspective seemed to be the most appropriate approach in the context of the collaborative translation project demonstrated in the present paper. The use of the transcreative approach in the project can be also justified by the fact that the participants were faced with a multitude of versions of traditional stories such as folk tales and legends, which had to be - in Lal's words - "edited, reconciled, and transmuted", simply because they had originally been passed on by word of mouth. Both these genres originate in oral tradition, which influences the existence of differences in detail, language and narration pattern in the numerous versions of folk tales and legends written down in the $20^{\text {th }}$ and $21^{\text {st }}$ centuries. Moreover, adapting traditional folk tales in order to make them attractive for foreign visitors is in agreement with the recent use of transcreation practices in the field of translating tourist texts (cf. Whyatt 2016: 106-107). In the context of tourism, transcreation of local traditional stories may serve as a marketing tool to promote a given region and its local folklore.

Practicing both literary and marketing-oriented transcreation while working on the Translating Folk Tales from Niedzica project has proven beneficial for translation students who participated in it and hopefully prepared them for future professional challenges such as translating advertising campaigns. The ability to adequately translate persuasive advertising content, often based (just as poetry and other literary works) on alliteration, assonance and wordplay, is obviously a desired skill in the repertoire of professional translators' competencies. Katan even advocates "the transcreational turn" in Translation Studies in order to save translational professions from disappearing in the era of constantly improving Google Translator apps and machine translation in general (2015: 378). And since "it is the (professionally-trained) translator who is uniquely placed to intervene and mediate between contexts to ensure optimum [intercultural] communication", individual professionals [i.e. translators and interpreters] "could 'simply' step into the role of transcreator, which would allow them to take advantage of an already 
assigned professional recognition of their creative role, and which would authorize them to take account of the impact of cultural distance when translating" (Katan 2015: 378). It seems then that transcreation workshops or courses should enter translator training curricula on a regular basis.

\section{The stages of the project}

Bearing all the above-mentioned issues in mind while designing the translationalethnographic event and the follow-up in-class activities, the translation trainers aimed at enhancing the students" "transcultural and sociolinguistic awareness", as recommended in the EMT Competence Framework (2017: 6). Moreover, locating the activities partly outside the classroom in an authentic setting not only helped "build a positive and effective teaching and learning environment", as GonzálezDavies (2004: 7) advocates, but also enabled understanding of the peculiarities of the visited region. A fieldtrip to the place associated with the tales fostered imagination and enhanced creativity among the students taking part in the project. As to the collaborative nature of the project, it was ensured that all of the features defining collaborative translation were present in the transcreation project described below, including "multi-participant synchronous and/or asynchronous interaction", "negotiating/discussing between participants", "a division/distribution of labor" and "mutual agreement" between participants (Thelen 2016: 261).

\subsection{Pre-translation phase in authentic setting}

The project started with a guided tour of Niedzica Castle, where "[h]istorical facts intermingle with legendary circumstances being enhanced with the mythological motifs" (Piotrowska 2019: 41). In situ, the students had the opportunity to learn of the castle's history which abounded in cultural and linguistic diversity. The multicultural and multilingual inhabitants of the Spiš land surrounding the castle were, until WWII, a melting pot of Polish, Hungarian, Slovak, Saxon, Wallachian, Jewish and Romany peoples. As a result, legends and folk tales from the region refer to their multicultural relations and ancestry, reflecting the rich mosaic of languages, dialects and traditions ${ }^{1}$.

Since legends and folk tales originate in the tradition of oral storytelling, what followed the guided tour of the castle was performance reading of legends and folk tales connected with the place and its past inhabitants. The reading was performed by volunteer students. The rest of the group who listened to the

1 For instance, there is a legend saying that the Hungarian Lord György Horváth-Palocsay of Niedzica caused the decline of his family due to a disgraceful deed which resulted in a Gypsy prophecy, a mythic tale of a Polish-Peruvian family hiding an Incan treasure in the castle and yet another folk story tells of a famous Polish-Slovak highland robber. 
performative reading confirmed that they could better understand the narration, feel the mysterious ambience and imagine past times. The legends were read aloud in different versions taken from volumes by Janicka-Krzywda (1996), Sala (2013), Szydlak-Sobala and Mściwujewski (2007) and from various websites promoting the region. "It was interesting to note that each legend or folk tale, whether amusing or perplexing in content, had several different versions in which not only epic details but also the modes of tale-telling varied considerably" (Mastela and Seweryn 2019: 5). As to the linguistic and literary character, the Polish versions represented different literary styles in the narrative parts and more or less distinctive speech styles or registers in dialogues and monologues (for example, Polish highlanders' dialect and rural varieties spoken by the representatives of the common people as opposed to the standard form of the language used by protagonists stemming from the upper class). These linguistic issues constituted translation problems which had to be solved by the studenttranslators at later stages of the project.

Next, the students formed groups of two to five people, chose one legend per group, analysed the most evident translation problems and thought how to solve them most creatively. In the context of Translation Studies issues, the discussions included ethnographic reflections on inter-linguistic and transcultural relations, different social groups, language varieties they spoke and cultural traditions they inherited. Finally, each group of students prepared and presented a draft version of their translation to be later elaborated and perfected in class throughout the semester. To sum up, the activities in the authentic setting of the medieval castle were a perfect introduction to the educational tasks that followed, namely comparative literature analysis, style-guide formation and collaborative translation.

\subsection{Classroom activities: from comparative analysis to transcreation}

The project continued within the frames of a specialised course in collaborative translation. Some activities took place inside the classroom, whereas other tasks were accomplished by students at home, later consulting in class and via e-mail or an electronic communication platform. Several classroom activities were aimed at preparing the students for the crucial task of transcreation or adaptation of the source texts for the target English-speaking audience. Based on the example of Rosemary Harris's "fresh interpretations of old tales" and her idea that folklore versions can be "recreated" (1974: note on the inside front cover), the primary goal of the project in question was to compile and recreate several Polish versions of Niedzica folk tales in English in such a way that they sounded interesting to foreign readers. The process of such creative re-writing or re-telling folk tales in a different language had to be preceded by various tasks. 


\subsubsection{Comparative analysis of parallel texts}

The first task was to study Polish sources - both folklore and literary - including the different versions of legends with which the students had already become familiar during their stay in Niedzica. The second task was to read and analyse Celtic legends (e.g. Delaney 1989) and other English-language folk tales (including those edited by Crossley-Holland 1987). The third task consisted of comparing the ways in which the Poles and the Anglo-Saxons tended to construe their legendary pasts (in order to detect similarities and differences) and then deciding what the characteristic features of the respective styles of folk storytelling were and which of those features should be reflected in translation in order to evoke the same effect and emotions in the target readers. In other words, what followed the comparative literature analysis was reflection and discussion on global transcreation and translation strategies as well as particular detailed translation techniques ${ }^{2}$.

\subsubsection{Creating a style-guide}

Later, on the basis of their comparative analysis of English-language editions of Celtic legends and other English-language folk tales, the students were asked in class to produce a style-guide. While doing this, they paid attention to: style and register (standard and non-standard/dialect vocabulary, syntax and so on), punctuation, paragraph structure and layout, as well as orthography (for example the spelling of the characters' names and the use of capital letters in other proper names such as the Pieniny and the Tatra Mountains, Niedzica Castle, and the Dunajec River).

Certainly, consistency with a style-guide should assure the quality of target texts, according to the ISO 17100 standard for Translation Service Providers. Above all, however, when translating texts belonging to a particular literary genre, such as legend or folk tale, one has to be aware of the genre's specific features of grammar and vocabulary, of the characteristic syntax and style. What the students noticed and enumerated on the basis of selected English-language legends included:

- picturesque detailed descriptions,

- chronological order of events,

- few / many archaisms (depending on the strategy chosen by editors),

- typical beginnings such as 'There was once a landlord...',

- repetitions,

- inversion,

- strange proper names,

- sophisticated vocabulary,

- high register, standard form, no colloquialisms; apart from some dialogues in which specific varieties and dialects may appear if the

2 For the definition of translation strategy and technique, see Piotrowska 2002: 63-65. 
characters come from rural areas and do not represent the court or aristocracy, nonstandard speech usually being used either to 'stress social class contrast' or to 'indicate local cultural features' (Newmark cit. in Berezowski 1997: 32).

All the above-mentioned specific features had to be somehow recreated in the English versions of the Polish legends and folk tales so that the target texts could appeal to the target audience. Therefore, on the level of the genre-specific qualities, the target texts written by the students who participated in the project generally resembled legends written originally in English since the translations (or transcreations) had to fulfil the same literary and communicative functions.

\subsubsection{Using brainstorming to solve translation problems (trans)creatively}

After preparing the style-guide, students received a home assignment to develop their draft versions (written at Niedzica Castle) according to the style-guide and in agreement with what they had learnt about Anglo-Saxon folk story-telling from the comparative analysis. Each group communicated on-line while working on the assignment and then brought their English versions of the tales to class for group discussion. Only the most troublesome or contentious problems were discussed in detail in order to find the best solutions. Each text as a whole was later revised and proofread by other students (cf. Section 2.4.1.).

After the analytical, structured process of comparing parallel texts representing two genres (folk tales and legends) to form a style-guide, it was time for a more relaxed method which would help to find creative solutions to particular translation problems: brainstorming. Students were encouraged to think of different ideas, for example, the titles, ways to render specific, sometimes meaningful proper names, dialect, archaic and culture-bound vocabulary. Some ideas seemed rather bold ${ }^{3}$ at first, but the main assumption of the brainstorming method is not to limit creativity. Judgments as to the appropriateness of given solutions were made jointly just before the end of the class. The main criterion was whether the chosen solution was likely to evoke the desired effect in the target readers. The brainstorming method proved to be perfectly compatible with the transcreative approach utilised by the project.

Examples of the most interesting translation problems ${ }^{4}$ together with students' proposals to solve them can be found below:

- How to achieve a sophisticated, slightly (but not too) archaic literary register $\rightarrow$ Words and phrases proposed by the students included: 'albeit', 'woe betide anyone...' (in The Legend of the White Lady and the Inca

3 For instance, a student thought of 'domesticating' the setting of a tale for the target readers by transforming the original south Polish Spiš land into a North American 'Western' setting, the Polish and Slovak highlanders into cowboys and the traditional Jewish inns into saloons. Another student opted for modelling legendary Polish outlaws on Robin Hood.

4 Cf. Piecychna (2013) and her study of translation problems (and their didactic implications) in rendering Irish fairy-tales into Polish. 
Treasure), 'damsel', 'apparel' (in The Legend of Gatajda's Flight) and 'dwell', 'fair lady' (in The Legend of Agnieszka and the English Knight).

- How to be politically correct and at the same time not lose the multicultural picture of the ancient setting $\rightarrow$ For instance, in order to describe a family of nomads who temporarily lived at the foot of Niedzica Castle, the students decided to use two words interchangeably depending on the attitude towards the nomads represented by other characters in the story: either the official, inoffensive adjective 'Romani/Romany/Roma' if the nomads were welcome or the slightly derogatory noun 'Gypsy' if they were despised.

- What certain culture-bound and folklore-bound terms mean and how to render them in English $\rightarrow$ For example: the students who worked on retelling the story of a highland chieftain did not understand the phrase wrzucić do basów, which literally means 'to throw [some money] into the double bass [strictly speaking, a cello-like instrument traditionally present in the Polish folk band]' and refers to an old Polish folk custom requiring people to pay the band for their music in advance otherwise the band would not play (e.g. at a wedding, one could request a desired folk dance by throwing a customary sum into the instrument). When the students learnt the explanation of the phrase, they decided to render it by means of a more general, easily understandable statement, using at the same time an archaic name for a silver coin, well known from legends and fairytales: "throw a golden thaler to ask the musicians to play" (The Legend of Galajda's Flight).

- How to make a title intriguing for the target reader $\rightarrow$ It seemed that it would be advantageous to use wordplay, which is so typical in English literary texts. ${ }^{5}$ In the case of one title "Jak Gałajda uciekał z niedzickiego zamku" [literally: How Gałajda absconded from Niedzica Castle] in Janicka-Krzywda (1996: 63-68), homonymy was applied: the tale was named The Legend of Gałajda's Flight since the English word 'flight' encompasses two meanings, both of which are relevant to the story; 'flight' as "the action or process of flying through the air" or as "the action of fleeing" (https://www.lexico.com/definition/flight), and the outlaw Gałajda escaped from his prison cell by flying out of the tower through a small window using his wide coat as wings.

\subsection{A look from another perspective: review by a native speaker}

An expert in communication and native-speaker of American English assessed the final versions of the tales provided by the students. Linguistic and editorial recommendations from the reviewer included among others:

5 Wordplay is also a tool frequently used in copywriting, which is basically a similar activity to the one performed by transcreators of, for example, advertising campaigns. 
- minor corrections of syntax or paragraph structure;

- avoiding too frequent use of pronouns 'it' and 'they', which might cause incomprehensibility of a paragraph;

- suggestions concerning lexical choices, e.g. the students were advised to use:

O 'robberhood' for 'robbery' instead of the archaic, rare Scottish 'reif',

0 the more common 'carriage' instead of the historical, rather royal-sounding 'barouche',

- simply 'money' instead of 'lolly', which is British informal for 'money' but could be misunderstood as a lollipop or some other sweet.

Briefly, it was recommended not to exaggerate with archaisms or nonstandard varieties of English. If the texts were aimed at contemporary speakers of English originating from various countries (not necessarily native speakers of that language), the meaning of words should be commonly understandable.

As an American, the reviewer also made the students and the teacher aware of the difficulties connected with the pronunciation of Polish words by English (native) speakers. She suggested preparing a short list of the most important Polish proper names appearing in the legends, together with the phonetic transcription of those words. However, professional transcription based on the International Phonetic Alphabet (IPA) and applied in dictionaries worldwide, though relatively easy in preparation thanks to the strict rules regulating the use of specific symbols for given consonants, short and long vowels, diphthongs and triphthongs, proved to be insufficient as not many people can actually read it. Addressed primarily at philology graduates and linguists, IPA transcription for the purpose of the project in question had to be accompanied by phonetic spelling for English native speakers. Preparing the latter proved more difficult because the students had to search for English words the syllables of which would sound almost like Polish syllables. Producing pronunciation guidelines for the target readers was a completely new experience to the students and they found it interesting in spite of the unusual character of the activity. 
Table 1. The Phonetic Transcription of Selected Polish Proper Names (Mastela and Seweryn 2019: 9)

\begin{tabular}{|c|c|c|}
\hline & $\begin{array}{ll}\text { International } & \text { Phonetic } \\
\text { Alphabet (IPA) } & \end{array}$ & $\begin{array}{l}\text { Phonetic spelling for native } \\
\text { English speakers }\end{array}$ \\
\hline Agnieszka & & ag-nYEsh-ka \\
\hline & /æg'niəJks/ & tha \\
\hline Dogusiaw & /bv'guswaf/ & bo-guU-suav \\
\hline Czorsztyn & /'t $\int \mathrm{pr} \int \mathrm{ttn} /$ & tchOr-schtin \\
\hline Dunajec & /dv'naretz/ & doo-nAH-yetz \\
\hline Gałajda & /g $\Lambda^{\prime}$ waIdə/ & gah-whY-dah \\
\hline Janosik & /jی'npsi:k/ & ya-nO-sheek \\
\hline Jurgów & /'jorgof/ & yOO-rgoof \\
\hline Łapszanka & $/ \mathrm{w} \Lambda \mathrm{p}^{\prime} \int \Lambda \mathrm{nk} \Lambda /$ & wap-shAn-ka \\
\hline Niedzica & /nıə'dzitzN/ & nyeh-jEE-tsa \\
\hline Pieniny & /pıə'nini/ & pyeh-nEE-nyh \\
\hline Rzepiska & /ze'pr:sks/ & zhe-pEAs-kah \\
\hline Stary Sącz & /sturr'spnt $f /$ & stAhr-ee sONtch \\
\hline Szymek & /'Simek/ & shIm-mek \\
\hline
\end{tabular}

\subsection{Other translation pedagogy issues}

\subsubsection{Collaboration and quality assurance in authentic projects}

It has become obvious in recent years that in order to meet the demands of the market and to prepare translation trainees for the specificity of international agencies specializing in providing language services such as translation, localization, post-editing, transcreation or other, students should be taught many different skills. As a translation education scholar remarks, "Moving beyond the text" and focusing on a larger translation project proves "an effective tool, teaching comprehensively various competences, including team work, time management, project management and terminology mining. Of relevance also [are] issues of professional ethics and conduct such as responsibility for one's own

6 Please, note that in the right hand column stressed syllables are marked with capital letters. 
work and meeting deadlines" (Dybiec-Gajer 2011: 163-164). In the project described in the present paper, the students moved "beyond the text" in many ways:

- they analysed different versions of each text in the source language and compared them with parallel texts of legends and folk tales written originally in the target language in order to prepare transcreations that would be appealing to the target audience,

- they were engaged in a collaborative project aiming at issuing a volume containing a collection of transcreated texts; they interacted in pairs and larger groups ${ }^{7}$, learned how to motivate one another, how to revise and proofread other students' work and how to provide constructive criticism,

- they were given considerable freedom in terms of choosing software and Internet platforms on which to communicate ${ }^{8}$,

- they travelled to the place from where the texts originated and acquired knowledge of the socio-cultural and historical background of the source texts.

As a result, the project fulfilled the conditions of "Situated Learning, [in which] learners become involved in a 'community of practice' where the student advances from 'novice', at the periphery of this community, to 'expert', at its centre" (González-Davies and Enríquez-Raído 2016). An additional motivating factor was a real-life purpose: the planned publication of the target texts prepared by the students? .

Apart from translator teams (consisting both of $1^{\text {st }}$ year and $2^{\text {nd }}$ year MA students), there were also people responsible for quality assurance. In accordance with the requirements included in the ISO 17100 standard for Translation Service Providers, some students (specifically $2^{\text {nd }}$ year MA students) assumed the roles of: project manager ( 1 person), IT assistants ( 2 people), revisers ( 6 people) and proof-reader (1 person). In order to ensure the best linguistic quality possible, the roles of revisers were assigned to those students who had at least a BA in English philology, whereas translations could be made by people who had received their BAs in any field. The revisers had the opportunity to learn how to correct mistakes at the level of language and register (such as spelling, grammatical or stylistic errors) and at the level of narration (cohesion, coherence, chronology; paragraph and story structure). The revision task was performed on-line. Some of the

7 Generally, the students worked in groups of 2-5; only one legend was retold by an individual student who did not attend the course but asked for permission to participate in the project. However, the legend prepared individually caused most problems, particularly at the revision stage, due to the lack of proper communication between the student and the group.

8 The group chose the collaboration software Slack and some students found it advantageous. However, not all of them used it regularly, which caused some communication problems and made meeting deadlines difficult.

9 The outcome of the project was the $2^{\text {nd }}$ volume of Translation Collections published by the Chair for Translation Studies and Intercultural Communication, Jagiellonian University in Kraków, in 2019. 
students preferred working on their revisions using GoogleDocs, which facilitated cooperation with the translators who could instantly see the reviser's corrections, answer their questions, correct mistakes or suggest better stylistic solutions. The proof-reader's task was to assure that all the target texts were consistent and conformed to the style-guide (previously prepared by the group), paying particular attention to the format, layout, orthography (especially proper names), punctuation (including consistency in the way in which dialogues were introduced to the narration), and so forth. The revisers and the proof-reader worked on their assignments partly at home but most of their decisions were later discussed in class.

\subsubsection{The role of the translation teacher}

The teacher's role in the entire process was multi-angled: it was that of "a guide and counsellor" as Maria González Davies (2004: 3) puts it, since in a transcreation project - even more so than in the case of more traditional/standard translation assignments - "Most questions simply do not have a closed answer and require discussion, negotiating and team work, as well as introspection" (González Davies 2004: 3). Nevertheless, students expected feedback, some found it probably more important than tutoring and counselling. Although the teacher tried to transfer onto the students much of the responsibility for setting and monitoring quality standards, as Dybiec-Gajer (2011: 162) recommends, some of the students apparently did not feel ready to accept responsibility for assessing the target texts. Moreover, even though the lecturer was ready to accept many of the students' choices, her intervention was sometimes necessary, for example in cases of incorrect uses of grammatical tenses in English or when there was no consistency in the register used in the narration or dialogues.

All things considered, the teacher must admit to having learnt a lot from guiding the students through the project. This seems to be in agreement with what González-Davies and Enríquez-Raído (2016) underline: "As the translation projects are real-life or very nearly so $[\ldots]$, the teachers learn alongside the students to a certain extent, as they cannot foresee all the problems that may arise and, so, have to leave room for the unexpected in the syllabus."

\section{The students' views of their learning experience}

After the proofreading stage (that is before the native speaker was consulted over the texts), an anonymous questionnaire in Polish, containing 9 open questions, was prepared where students were asked to reflect on various issues connected 
with the project ${ }^{10}$. Below are the questions and the most interesting excerpts from the answers given by the students (transl. from Polish: O.M.):

1. What did you learn as translator [Students A-I] / reviser [Students J-L] / proof-reader [Student M] / project manager [Student N] / IT assistant [Students O-P] in terms of:

a) literary translation, transcreation, adaptation, translation strategies?

- Student A: "It was the first time I had participated in such a huge project focused on transcreation; I learned more about transcreation as well as about the structure of legends in both Polish and English. Thanks to the project, I could improve my ability to write in the form of the English language no longer used at present, one which abounds in archaisms and is stylised to sound like the language spoken centuries ago."

- Student C: "[I learnt]:

- how to cope with the translation of proper names;

- that it's crucial to decide first whether to exoticize or to adapt;

- that it's sometimes worth finding similar texts [in the target language] to facilitate and enhance your job".

- Student D: "I realised how important the role of the reviser and proofreader was in helping to improve the quality of the final version of the text. [...] I found transcreation - that is departing from complete faithfulness to the source text and transforming the target text in a freer way - very interesting".

- Student H: "[I realised] the importance of style-guides including orthography and punctuation guidelines".

- Student I: "In order to render the 'spirit' of a given text, it is worth looking at various parallel texts in the target language."

- Student J: "Phrasal verbs and colloquial vocabulary don't match the register of legends written in English".

- Student M: “Working as a proof-reader, I understood the specificity of the job and how challenging it is to ensure the consistency of texts translated by many different people".

b) project organisation?

- Student F: "Fluent cooperation with the group; reaching agreement in matters of argument concerning translation."

- Student D: "How to collaborate with a bigger group of people you don't know personally".

- Student C: "[...] keeping the deadlines; listening to suggestions of other people; assigning one person responsible for checking the consistency of the text, including the forms and spelling of names and proper nouns".

2. How did you feel in the role that had been assigned to you? Why?

10 The total number of 31 students took part in the project (14 completing their $1^{\text {st }}$ year of the MA cycle and 17 in their $2^{\text {nd }}$ year), but for reasons independent of the teacher-researcher only 19 of them ( 9 from the $1^{\text {st }}$ year and 10 from the $2^{\text {nd }}$ year) completed and submitted the questionnaire. 
- Student E: "I enjoyed my role very much. [...] I coordinated a group of translators [responsible for one folk tale], which was a new experience to me. I learnt a lot from combing parts of the text translated by me and other students; from the contact with revisers and from discussions within the group."

- Student K: "I played the role of reviser. I wish I had been assigned the role of translator."

- Student M: "I felt good thanks to the teacher's counselling and support."

3. Which one of the roles mentioned in the first question would you like to play in the next collaborative project?

- Student K: "In the next project, I would like to play the role of translator since I prefer translating texts to correcting a text translated by someone else".

- Student I: "Perhaps the role of proof-reader".

- Student M: "The proof-reader's role suits me".

- Student O: "I enjoy working on terminology and I hope that in the future, if we work on a similar project, I will be allowed to assume the role of terminologist".

4. What did you find the most difficult while working on the project?

- Student A: "Transcreating Niedzica legends was a big challenge since one had to decide what to do with the numerous 'culturemes' present in the legends, how to render the culture-bound items in translation. Another difficulty was caused by dialogues written in Polish highlanders' dialect in the original; the question was what the optimal translation strategy would be in case of such dialogues."

- Student B: "Some of the archaic Polish phrases and searching for their English equivalents".

- Student G: "[...] It was difficult to communicate with everyone. Working in a group always constitutes a challenge for me because I like working on my own."

- Student M: "Different styles represented by different translators; syntax and vocabulary that are characteristic of legends but different from the standard use of English".

5. What kind of assistance, guidelines, feedback would be needed in another project of this type?

- Student L: "More additional reference materials; more extensive discussion of strategies chosen by translators."

- Student P: "More feedback about the progress [in work]."

- Student O: [No idea].

- Student G: "[...] it would be good to create a glossary of repeating terms".

6. How do you assess the cooperation with revisers/translators? 
- Student M: "It depends on the person. Some texts had been well elaborated, which enabled me to focus on my task, that is the final proofreading. In other cases texts had been neither carefully translated nor accurately revised, which made me verify the texts before proceeding to the proof-reading stage".

- Student N: "The cooperation was quite good, however I had to remind people of the deadlines and motivate them to do their jobs".

7. What should be modified in order to improve cooperation in collaborative translation projects in the future?

- Student J: "More strict deadlines."

- Student C: "Perhaps more frequent meetings (with other groups) to enable more brainstorming to share ideas".

- Student A: "I would change the communication platform".

8. How do you assess the quality of management provided by the project manager?

- Student K: "Very good".

- Student I: "Good".

- Student G: "In my view, collaboration through the communication platform 'Slack' was very smooth".

- Student D: "To be frank, [...] I haven't noticed the management process."

9. What should be modified in order to avoid potential problems in projects to come?

- Student P: [Nothing]

- Student O: "It would be better if the time frames of the subsequent stages of the project [translation, revision, proof-reading] were more definitely indicated in the beginning".

- Student J: "Keeping the deadlines".

- Student M: "Joint work on terminology before starting a project".

- Student G: "Perhaps more preparatory exercises before starting translation. For instance [...] to practice inversion, archaising, emphasis, cleft-sentences etc., depending on the themes of the projects".

\section{The didactic implications of the qualitative analysis of students' views}

Based on the qualitative analysis of the answers, it can be said that the respondents appreciated the novelty of the assignment since they had never practised transcreation or adaptation before. Answers to question 1 prove that the students understood what transcreation meant and had the opportunity to practice it within the frames of the project. The contact with slightly archaic language and the specific literary style which characterises legends was also new to many of the participants and they found it difficult to write in English which would not sound too contemporary. Some respondents suggested more practice in linguistic and 
stylistic matters be given before further projects of this kind. Almost all the students emphasised the importance of group work experience, joint effort of collaboration in translation teams, receiving feedback from the revisers, being coresponsible for the final product. Suggestions for the future included: more reference materials, more preparatory exercises, better time management, stricter deadlines, shorter parts of texts to be translated at one time by one person, more feedback from revisers, testing other communication platforms and software. Many respondents were satisfied with the roles assigned to them, however some would be eager to accept a different role in another project in order to gain a different sort of experience. Interestingly enough, two respondents would definitely not want to be responsible for revision in the future. One of them was a $2^{\text {nd }}$ year MA student who had been assigned the role of reviser and judged this experience less interesting and less valuable than that of translator or transcreator. The other student was in their $1^{\text {st }}$ year of the MA programme, worked in a group of translators and would prefer to continue as translator, since in their opinion revision would be too difficult and too responsible a task at this stage of education. All in all, the questionnaire has shown that the students learnt a lot from the project and would be willing to take part in another to gain even more experience in transcreation and team collaboration.

Continuing the action research, another project of this kind was coordinated by the same teacher-researcher in the spring semester of the academic year 2019/2020 with another group of MA students. Answers to all the questions mentioned in Section 3, in particular to questions 5, 7 and 9, helped to improve the organisation of a similar project on English transcreations of legends and folk tales from other regions of Poland. The observations noted by the participants of the pilot study and by the teacher-researcher herself proved beneficial for the next project. The improvements included:

- a general comparative introduction to Polish and Celtic folklore,

- more reference materials and parallel texts (some brought to class by the students, other provided by the teacher-researcher and a professional story-teller and writer $)^{11}$, which enabled students to detect the peculiarities of folk tale telling in Polish and in English,

- more detailed analysis of the sources as well as the lexical and stylistic issues concerning each legend/folk tale to be translated/transcreated,

- more brainstorm discussions of possible translation, transcreation and adaptation strategies and techniques,

- stricter deadlines,

- more lectures and reflection on the issues of project management and quality assurance,

- using other communication platforms and software,

11 Here acknowledgements are due to Stephanie AW Bradley, MA, for sharing with the students her list of folk tale devices in English and for reviewing the transcreations of folk tales to be published in vol. 4 of Translation Collections (ed. Mastela 2020; in print). 
- preparing a glossary apart from a style-guide.

\section{Conclusions}

The objective of this paper was not only to present an authentic collaborative project but also to demonstrate the advantages of applying the transcreative approach to translation in translator training at MA level. Though the number of project participants was not large enough to justify quantitative research, it permitted a qualitative action research pilot study on the basis of the observations made by the teacher-researcher in classroom and authentic settings as well as on the basis of students' views expressed in a questionnaire. The results of the study have not provided enough empirical data to serve as a basis for drawing conclusions about translator education in general, but they have clearly indicated that including transcreation activities in a collaborative translation course is possible and beneficial.

The students in the investigated sample responded actively to the project's transcreative focus. They found various preparatory and main transcreative tasks (such as performative reading in an authentic environment, comparative analysis, creation of a style-guide for a specific literary genre, and re-writing the source text creatively) very insightful. The project participants appreciated the transcreative training also as a means to develop creativity in finding the best strategies and solving particular translation problems both individually and collaboratively. The transcreative task of 're-writing' Polish folk tales for a foreign audience seems to have encouraged students to use their imagination, solve translation problems more creatively, look for synonyms in particular registers and apply stylistic and narrative devices to capture the target reader's attention. The students' imaginative ways of combining several different Polish versions of Niedzica folk tales and rendering them into the English language resulted in original adaptations, rich in new, interesting images of the legendary scenery, characters and events. Having adapted the sources to the genre-specific qualities of Anglo-Saxon folk tales, the students participating in the pilot study project succeeded in transferring the local colour of the southern Polish Spiš land and the emotional layer of the tales in a way that is attractive to (native) English speakers, thus fulfilling the idea of the transcreative approach to translation.

A conclusion can be drawn that designing and conducting an original collaborative translation course including elements of transcreation training may help motivate students and equip them with many different skills. This kind of translation/transcreation course may be also beneficial to those who teach it. The teacher's creativeness and open-mindedness are enhanced, since he or she can never be sure how a given course or project will develop; students can ask many unexpected questions concerning both collaboration and transcreation, as well as contribute many interesting ideas for solving translation problems and adapting 
texts creatively. Last but not least, transcreatively oriented translator training would seem to prepare future translators for the needs of the contemporary translation market.

The use of the transcreative approach to translation in the field of translator training requires further research, though, preferably in both kinds of environment: in and out of the classroom. For example, it would be interesting to investigate through empirical research how people who have participated in transcreation courses during their MA programme at the university perform later as professionals in comparison to those who have not received such training or if and how the former graduates apply what they have learnt in transcreation classes in their professional careers as language service providers.

To conclude, research on the applicability and potential advantages of the transcreative approach to translation in translator education should be continued as it may contribute to the enrichment of university level translation training curricula and in the long run to the widening of employment opportunities for graduates.

\section{References}

Bassnett, Susan and Harish Trivedi. 1999. Post-Colonial Translation: Theory and Practice. London and New York: Routledge.

Berezowski, Leszek. 1997. Dialect in translation. Wrocław: Wydawnictwo Uniwersytetu Wrocławskiego.

Bowers, Chet. 1997. The Culture of Denial. Albany: State University of New York Press.

Crossley-Holland, Kevin. (ed.) 1987. The Northern Lights. Legends, Sagas and Folk-tales. London and Boston: Faber and Faber.

Delaney, Frank. 1989. Legends of the Celts. $1^{\text {st }}$ ed. Glasgow.

Dybiec-Gajer, Joanna. 2011. Wyjść poza tekst - projekt tłumaczeniowy jako narzędzie samooceny i autorefleksji w dydaktyce przekładu specjalistycznego. In M. Krajewska, L. Zieliński (eds.), Studia nad teoria, praktyka $i$ dydaktykq przekładu. Toruń: Wydawnictwo Naukowe Uniwersytetu Mikołaja Kopernika. (Rocznik Przekładoznawczy 6) 151-164. https://doi.org/10.12775/RP.2011.011

Dybiec-Gajer, Joanna and Riitta Oittinen. 2020. Introduction: Travelling beyond Translation Transcreating for Young Audiences. In Joanna Dybiec-Gajer, Riitta Oittinen and Małgorzata Kodura (eds.), Negotiating Translation and Transcreation of Children's Literature. From Alice to the Moomins. Singapore: Springer. 1-9. https://doi.org/10.1007/978-981-15-2433-2_1

EMT Competence Framework 2017. [Online] Available from: https://ec.europa.eu/info/sites/info/files/emt_competence_fwk 2017 en_web.pdf._[Accessed: 3rd January 2020].

EN ISO 17100:2015. Translation Services. Requirements for translation services. Brussels: European Committee for Standardization.

Frérot, Cécile, Lavault-Olléon, Elisabeth and Lionel Karagouch. 2019. Designing an Authentic Translation Environment for Future Translators: Integrating a Collaborative and Ergonomic Perspective into Translator Training. In Paulina Pietrzak (ed.), New Insights into Translator Training (inTRAlinea Special Issue). [Online] Available from: http://www.intralinea.org/specials/article/designing an authentic translation environment for future translators. [Accessed: $30^{\text {th }}$ December 2019]. 
Gambier, Yves and Jeremy Munday. 2014. A conversation between Yves Gambier and Jeremy Munday about transcreation and the future of the professions. In David Katan and Cinzia Spinzi (eds.), Transcreation and the Professions. [Online] CULTUS. The Journal of Intercultural Mediation and Communication, 7, 20-36. Available from: http://www.cultusjournal.com/index.php/archive/16-issue-2014-v-7-transcreation-and-theprofessions [Accessed: 19 $9^{\text {th }}$ August 2020].

Gill, Rosalind M. and María Constanza Guzmán. 2011. Teaching Translation for Social Awareness in Toronto. In Mona Baker and Carol Maier (guest eds) Ethics and the Curriculum [The $\begin{array}{llll}\text { Interpreter and Translator } \quad \text { Trainer, } & \text { 53-108. }\end{array}$ https://doi.org/10.1080/13556509.2011.10798813

González-Davies, Maria. 2004. Multiple Voices in the Translation Classroom. Activities, tasks and projects. Amsterdam and Philadelphia: John Benjamins Publishing Company. https://doi.org/10.1075/btl.54

González-Davies, Maria and Vanessa Enríquez-Raído. 2016. Situated learning in translator and interpreter training: bridging research and good practice. In The Interpreter and Translator Trainer, 10(1). 1-11. [Online] Available from: https://www.tandfonline.com/doi/full/10.1080/1750399X.2016.1154339. [Accessed: $30^{\text {th }}$ December 2019]. https://doi.org/10.1080/1750399X.2016.1154339

Harris, Rosemary. 1974. The Lotus and the Grail. Legends from East to West. London: Faber \& Faber.

Janicka-Krzywda, Urszula. 1996. Legendy Pienin. Kraków: Forma.

Katan, David. 2014. Uncertainty in the Translation professions. In David Katan and Cinzia Spinzi (eds.) Transcreation and the Professions. [Online] CULTUS. The Journal of Intercultural Mediation and Communication 7. 10-19. Available from: http://www.cultusjournal.com/index.php/archive/16-issue-2014-v-7-transcreation-and-theprofessions. [Accessed: $19^{\text {th }}$ August 2020].

Katan, David. 2015. Translation at the cross-roads: Time for the transcreational turn? In Perspectives. Studies in Translation Theory and Practice, 24(3), 365-381. https://doi.org/10.1080/0907676X.2015.1016049

Kiraly, Donald C. 2012. Skopos Theory Goes to Paris: Purposeful Translation and Emergent Translation Projects. In Hanna Risku, Christina Schäffner and Jürgen Schopp (eds.), sed sensum exprimere de sensu In memoriam Hans J. Vermeer. Special issue of mTm to commemorate Hans J. Vermeer. [Online] $m T m-A$ Translation Journal. Athens: Diavlos. 119-144. Available from: http://www.mtmjournal.gr/datafiles/files/MTM 4.pdf. [Accessed: 20th August 2020].

Kiraly, Donald C. et al. 2016. Towards Authentic Experiential Learning in Translator Education. Göttingen: V\&R Unipress, Mainz University Press.

Lal, Purushottama. [1957] 1964. Great Sanksrit Plays in New English Transcreations. NewYork: New Directions Publishing. https://doi.org/10.14220/9783737004954

Mastela, Olga and Agnieszka Seweryn. (eds.) 2019. Translating Folk Tales from Niedzica/Ttumaczenie legend niedzickich (Translation Collections 2).

Morón, Marián and Elisa Calvo. 2018. Introducing transcreation skills in translator training contexts: A situated project-based approach. The Journal of Specialised Translation 29. 126-148.

Pedersen, Daniel. 2014. Exploring the Concept of Transcreation - Transcreation as 'more than Translation'? In David Katan and Cinzia Spinzi (eds.) Transcreation and the Professions. [Online] CULTUS. The Journal of Intercultural Mediation and Communication 7. 57-71. Available from: http://www.cultusjournal.com/files/Archives/pedersen 5 p.pdf. [Accessed: $19^{\text {th }}$ August 2020].

Piecychna, Beata. 2013. Problemy thumaczeniowe w przekładzie irlandzkich baśni - implikacje translatologiczne i dydaktyczne. Białostockie Archiwum Językowe 13. 253-274.

Piotrowska, Maria. 2002. A Compensational Model for Strategy and Techniques in Teaching Translation. Kraków: Wydawnictwo Naukowe Uniwersytetu Pedagogicznego w Krakowie. 
Piotrowska, Maria. 2019. Cultural Identity Through Myth and Legend. In O. Mastela and A. Seweryn (eds.), Translating Folk Tales from Niedzica/Ttumaczenie legend niedzickich (Translation Collections 2), 37-50.

Piotrowska, Maria. 2020. Transcreation Projects in Ethnographic Research and Translation Studies. [Online] In INTED2020 Proceedings. 6041-6041. Available from: https://library.iated.org/view/PIOTROWSKA2020TRA. [Accessed: 20th August 2020].

Sala, Bartłomiej Grzegorz. 2013. Legendy zamków karpackich. Olszanica: Wydawnictwo BOSZ.

Szydlak-Sobala, Irena and Seweryn Mściwujewski. 2007. Opowieści o zamku niedzickim. 3rd edn. Kraków: Forma.pl.

Thelen, Marcel. 2016. Collaborative translation in translator training. In Konin Language Studies / KSJ, 4(3), 253-269.

Toudic, Daniel and Alexandra Krause. 2017. Foreword. In 'EMT' Competence Framework 2017. [Online] Available from: https://ec.europa.eu/info/sites/info/files/emt competence fwk 2017 en web.pdf. [Accessed: $30^{\text {th }}$ December 2019].

Vieira, Else Ribeiro Pires. 1999. Liberating Calibans: Readings of Antropofagia and Haroldo de Campos' Poetics of Transcreation. In Susan Bassnett and Harish Trivedi (eds.) Postcolonial Translation: Theory and Practice, 95-113. London and New York: Routledge.

Whyatt, Bogusława. 2016. Tłumacz w branży turystycznej. In Bogusława Whyatt et al. Ttumaczpraktyczne aspekty zawodu, 103-123. Poznań: Wydawnictwo Naukowe UAM. 